\title{
Self-Medication among Health Workers during the COVID-19 Pandemic in Southern Nigeria: Knowledge, Patterns, Practice and Associated Factors
}

\author{
Josephine Enekole Aitafo ${ }^{1,2}$, Woroma Wonodi ${ }^{1,2}$, Datonye Christopher Briggs ${ }^{1,2}$, \\ Boma Awoala West ${ }^{1,2}$
}

\begin{abstract}
${ }^{1}$ Department of Paediatrics, Rivers State University Teaching Hospital, Port Harcourt, Rivers State, Nigeria ${ }^{2}$ Department of Paediatrics and Child Health, College of Medical Sciences, Rivers State University, Nkpolu, Port Harcourt, Rivers state, Nigeria.
\end{abstract}

Corresponding Author: Josephine Enekole Aitafo

DOI: https://doi.org/10.52403/ijhsr.20220223

\begin{abstract}
Background: The scare from the morbidity and mortality caused by the novel COVID-19 disease has continued with no specific cure in sight and many persons, including health care providers have resorted to self-medication. The study was intended to ascertain the prevalence of self-medication against COVID-19 among health workers in Rivers State.

Methodology: A cross-sectional survey of health workers in Rivers State was carried out using selfadministered questionnaires on self-medication against the COVID-19 disease from January 2021 to March 2021. Data were analyzed using the statistical package for social sciences (SPSS) version 25.0. Results are presented in charts and tables and a p-value of $<0.05$ was significant.

Results: A total of 220 responses were received from health workers, $50 \%$ of whom worked in private hospitals. Only 35 (15.9\%) of them reported to have ever indulged in self-medication for COVID-19. The most common drugs used for self-medication were Vitamin C, Zinc. Azithromycin, antimalarials (other than Hydroxychloroquine) and Hydroxychloroquine. Most medications were selfprescribed and procured from the pharmacies. Most persons (80\%) who self-medicated did so for fear of being infected following contact with suspected or confirmed COVID-19 cases or following sudden emergency illnesses.

Conclusion: Self-medication against COVID-19 is present among health workers in Rivers State and commonest among those who have tertiary level of education, those who are doctors and those who work in a public health facility.
\end{abstract}

Key words: Self-medication, Health workers, Covid-19, Pandemic, Nigeria

\section{INTRODUCTION}

Covid-19, a zoonotic disease caused by a novel coronavirus 2 (SARS-CoV-2) is a new respiratory infection first detected in December 2019 in Wuhan, China ${ }^{1}$ and has since then spread rapidly all over the world. The World Health Organization (WHO) declared it a public health emergency in
January, 2020 and in March $11^{\text {th }}$ 2020, it was declared a pandemic., ${ }^{2,3}$

Globally as at December $27^{\text {th }} 2020$, there were 79,232,555 confirmed cases, $1,754,493$ deaths with a case fatality rate of $2.2 \%$ whereas in Africa, 2,644,112 cases were confirmed positive 62,366 deaths with a case fatality rate of $2.4 \% .^{4}$ In Nigeria however, the first case of Covid-19 was 
detected on $27^{\text {th }}$ February, 2020 in the city of Lagos and has since then spread to all the states in the country. ${ }^{5}$ As at $27^{\text {th }}$ December, 2020 the total number of confirmed cases was 84,414 and 1,254 deaths with a case fatality rate of $1.5 \% .{ }^{4,5}$

In a bid to curb the spread of the virus, considering the fact that there is no definitive cure for the disease, lock down measures were introduced in various countries of the world including Nigeria as advised by the WHO in addition to adherence to various preventive measures such as social/physical distancing, regular washing of hands or use of alcohol-based rubs and the wearing of masks etc. Very high fatality rates were reported in Europe and America despite advanced health care systems ${ }^{6}$ which caused heightened anxiety and fear in the poorer countries of the world especially Sub-Saharan Africa where there is poor infrastructural health development and technical know-how. ${ }^{7}$ In addition, the WHO expressed worse fears of morbidity and mortality resulting from Covid-19 infection in Sub-Saharan Africa as compared to the developed nations. ${ }^{7}$

This fear and anxiety therefore led to people including Nigerians resorting to the consumption of various substances without medical advice either to prevent the disease or for its treatment. ${ }^{8}$ The use of these substances was worsened by fake news about the disease including information on various preventive and treatment options still undergoing trials on social media. These substances ranged from traditional medicines to different drugs bought overthe-counter (OTC). ${ }^{8}$

Self-medication (SM) can be defined as the intake of drugs, herbs or home remedies for physical or psychological ailments based on one's own initiative or on the advice of another person without consulting a medical doctor. ${ }^{9}$

SM is of global concern observed in both developed and developing countries of the world with prevalence of $32.5-81.5 \%$ world-wide. ${ }^{10,11,12}$ The incidence of SM may be higher in the low and middle income countries. ${ }^{13}$ In Nigeria, the prevalence of SM before the pandemic was high varying between 52.1 - 92.3\%. ${ }^{14-16}$ During the pandemic however, studies showed a prevalence of SM of at least one product ranging from $34.2-57 \% .{ }^{17,18}$

SM is usually suggested by friends, family members, neighbours, pharmacists as well as repetition of previous prescriptions and from the media.

SM may be of advantage if practiced correctly as it reduces the economic burden on patients especially in developing countries where cost of hospital treatment may be high, reduces pressure on the health care system as well as health management organizations. ${ }^{11}$ It however leads to polypharmacy, wastage of resources, increase in the price of the drugs due to excessive demand, antibiotic resistance, incorrect diagnosis and serious health hazards such as adverse drug effects, drug interactions as well as prolonged morbidity and mortality. ${ }^{10,}{ }^{19-22}$ In addition, SM is associated with incorrect dosage, wrong route of administration, prolonged use, improper storage as well as risk of dependency and abuse. Thus, SM has been described as a serious public health problem globally. It is pertinent to note that there were cases of mortality reported in the USA and Nigeria resulting from self-medication (the use of chloroquine) during the pandemic. $^{23,24} \mathrm{SM}$ also leads to stockpiling resulting in shortage of drugs for patients that genuinely need them.

Wegbom et $\mathrm{al}^{25}$ in Nigeria documented vitamin $\mathrm{C}$ and other multivitamins as the commonest drugs used for SM during the Covid-19 pandemic followed by hydroxychloroquine/ chloroquine, amoxicillin, ciprofloxacin and herbal products. Vitamin $\mathrm{C}$ was also observed as the commonest drug followed by traditional medicines, hydroxychloroquine/chloroquine and azithromycin by Sadio et $\mathrm{al}^{17}$ in Togo. In contrast, Nasir et $\mathrm{al}^{26}$ in Dhaka city, Senegal, reported Ivermectin as the commonest SM drug followed by 
azithromycin, Montelukast, calcium supplement, doxycycline and hydroxychloroquine whereas Quispe-Canari et al ${ }^{27}$ in Peru reported acetaminophen and ibuprofen as the commonest SM drugs followed by antiretrovirals, hydroxychloroquine and penicillins.

The present study was therefore carried out to determine the knowledge, practice, patterns of self-medications as well as its associated factors among health workers in southern Nigeria as no study of this nature has been carried out to the best of our knowledge. Findings from this study would help in the making of policies on the enforcement of drugs sold over the counter, proper pharmaceutical advertisements and thus help strengthen the health care system.

\section{METHODOLOGY}

Study design: The study was a crosssectional survey conducted from $2^{\text {nd }}$ of January 2021 to $2^{\text {nd }}$ of March, 2021 using a hybrid self-administered questionnaire (hard copy and online versions). The online version of the questionnaire was formed using a google questionnaire (docs.google.com/forms). The hybrid format was opted for to ensure a wide spread of the survey tool for better representativeness.

Study population: Participants were only healthcare professionals (doctors, nurses, and other allied healthcare workers) living in Rivers State.

Sample size calculation: The minimum sample size of 215 was calculated using the Cochran formula for cross-sectional studies at $95 \%$ confidence interval, $7 \%$ margin of error, $10 \%$ attrition and based on a selfmedication prevalence of $52.1 \%$ from a period study. ${ }^{15}$ A total of 220 health workers participated in the study which was considered adequate for the population of Health workers in Port Harcourt, Rivers state.
Inclusion criteria: Participants must be health workers in Port Harcourt and residing in the state during the COVID-19.

Questionnaire Design: The survey questionnaire was divided into five sections; Socio-demographic characteristics, knowledge and awareness of selfmedication, pattern of medications used for self-medication, reasons for selfmedications and treatment preferences for health workers who did not self-medicate. The socio-demographic variables included age, gender, marital status, religion, place of residence, level of education, occupation, average income, status designation, local government area of practice and place of practice. The knowledge of self-medication had 3 items, the pattern of medications used for self-medication had 4-subcategories with 33 items, the reasons for self-medication had 12 items and preference of treatment for health workers who did not self-medicate had 11 items.

Data collection: The aim of the study was explained to all participants. Those who gave consent were recruited into the study both online and offline. Both online and offline versions were retrieved immediately after completion. The online versions were distributed via emails and social media platforms using a link. The forms were filled over 2 months from $2^{\text {nd }}$ of January 2021 to $2^{\text {nd }}$ of March, 2021. Consent was obtained from all participants and confidentiality maintained.

Data analysis: The data collected were entered analysed using the Statistical Package for Social Sciences (SPSS) IBM version 25.0 (Armonk, NY). For the purpose of analysis, the correct answers were scored as two and wrong answers zero. The total score was converted to percentages and categorized as good knowledge $(\geq 70 \%)$ and not good knowledge $(<70 \%)$. Baseline characteristics of study participants were analysed using descriptive statistics. Categorical variables were 
presented as percentages and frequencies and continuous variables expressed as mean and standard deviation. Associations between the health workers' knowledge and practice of self-medication and their sociodemographic variables were tested using the Chi-square test with the demographic characteristics as the explanatory variables.

\section{RESULTS}

\section{Sociodemographic characteristics of respondents:}

A total of 220 health workers across Rivers State returned appropriately filled questionnaires. Females predominated (135 $-61.4 \%)$ with a $\mathrm{M}: \mathrm{F}=1: 1.6$ and the mean age of the health workers was 35.9 years. Of the 220 respondents, $110(50.0 \%)$ were doctors, $115(52.3 \%)$ were located outside of the Port Harcourt LGA and 185 (84.1\%) resided in the urban areas of the State. Almost all respondents, 215 (97.7\%) were Christians, $129(58.6 \%)$ were married and $194(88.2 \%)$ had tertiary level of education. Half $(50.0 \%)$ of respondents were privately employed, $119(54.1 \%)$ worked in private establishments and $112(50.9 \%)$ earned between $\$ 100,000$ to $\$ 500,000$ as seen in Table 1.

\begin{tabular}{|c|c|c|}
\hline 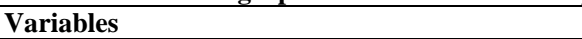 & Frequency & Percent $(\%)$ \\
\hline \multicolumn{3}{|l|}{ Gender } \\
\hline Female & 135 & 61.4 \\
\hline Male & 85 & 38.6 \\
\hline \multicolumn{3}{|l|}{ Marital status } \\
\hline Married & 129 & 58.6 \\
\hline Not married & 91 & 41.4 \\
\hline \multicolumn{3}{|l|}{ Educational status } \\
\hline Tertiary & 194 & 88.2 \\
\hline Non-tertiary & 26 & 11.8 \\
\hline \multicolumn{3}{|l|}{ Place of residence } \\
\hline Rural & 35 & 15.9 \\
\hline Urban & 185 & 84.1 \\
\hline \multicolumn{3}{|l|}{ Religion } \\
\hline Christian & 215 & 97.7 \\
\hline Islam & 2 & 0.9 \\
\hline None & 3 & 1.4 \\
\hline \multicolumn{3}{|l|}{ LGA of practice } \\
\hline PHALGA & 105 & 47.7 \\
\hline Non-PHALGA & 115 & 52.3 \\
\hline \multicolumn{3}{|l|}{ Status Designation } \\
\hline Auxiliary Nurse/ Nurse Assistant & 29 & 13.2 \\
\hline CHEW & 2 & 0.9 \\
\hline Doctor & 110 & 50.0 \\
\hline Laboratory scientist/ technician & 3 & 1.4 \\
\hline Nurse/ Midwife & 33 & 15.0 \\
\hline Pharmacist & 18 & 8.2 \\
\hline Warden & 4 & 1.8 \\
\hline Non-medical health care staff & 21 & 9.5 \\
\hline \multicolumn{3}{|l|}{ Place of practice } \\
\hline General Hospital & 7 & 3.2 \\
\hline Military Hospital & 6 & 2.7 \\
\hline Primary Health Centre & 15 & 6.8 \\
\hline Private Establishment (Hospital/ Clinic/ Maternity) & 119 & 54.1 \\
\hline RSUTH & 39 & 17.7 \\
\hline UPTH & 34 & 15.5 \\
\hline \multicolumn{3}{|l|}{ Occupation status } \\
\hline Government employed & 96 & 43.6 \\
\hline Private employed & 110 & 50.0 \\
\hline Self employed & 6 & 2.7 \\
\hline Unemployed & 8 & 3.6 \\
\hline \multicolumn{3}{|l|}{ Average Income } \\
\hline Less than $₫ 100,000$ & 80 & 36.4 \\
\hline$\$ 100,000-\$ 500,000$ & 112 & 50.9 \\
\hline Above $\$ 500,000$ & 28 & 12.7 \\
\hline
\end{tabular}




\section{Health workers' knowledge of self- medication:}

All respondents were aware of COVID-19. Less than two-thirds (57.3\%) had good knowledge of what was meant by

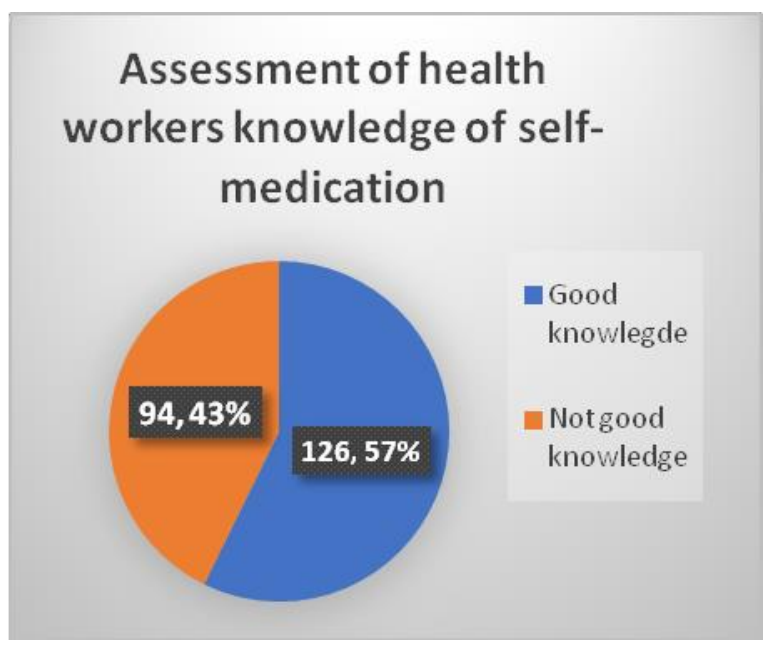

Figure1: Health workers knowledge of self-medication

\section{II: PATTERN OF DRUGS USED FOR SELF MEDICATION}

Table 2A demonstrates that the top five medications used by health workers who self-medicated were Tabs Vitamin C, Tabs Zinc, Tabs Azithromycin, Antimalarials (other than HCQ) and Hydroxychloroquine. The side effects reported by health workers were few and consisted of frequent passage of loose stools self-medication and only 35 (15.9\%) of health workers reported to have ever indulged in self-medication for COVID-19, as seen in Figures 1 and 2 respectively.

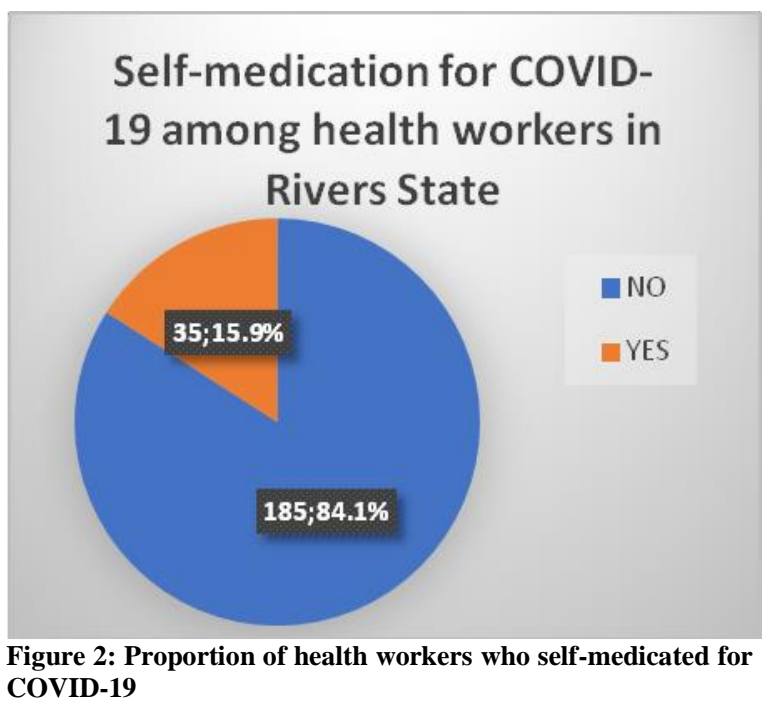

in $6(17.1 \%)$ persons and vomiting in 1 (2.9\%) person respectively, as seen in Table 2B. Over four-fifths $(88.6 \%)$ of respondents who indulged in self-medication reported that prescriptions for COVID-19 were done by themselves without a COVID-19 confirmatory test as shown in Table $2 \mathrm{C}$. The pharmacy was reported as the main source of the medications with which respondents self-medicated, as seen in Table 2D.

\section{Pattern of medications used for self-medication by health workers in Rivers state}

\begin{tabular}{|c|c|c|}
\hline \multicolumn{3}{|c|}{ Table 2A: Types of medications used by respondents } \\
\hline Medication used & Frequency $(\mathbf{n}=35) * *$ & Percentage $(\%)$ \\
\hline Vitamin C & 34 & 97.1 \\
\hline Zinc & 28 & 80.0 \\
\hline Hydrochloroquine/chloroquine & 12 & 34.3 \\
\hline Multivitamins & 11 & 31.4 \\
\hline Antimalarials (not hydroxychloroquine) & 16 & 45.7 \\
\hline Azithromycin & 24 & 68.6 \\
\hline Erythromycin & 2 & 5.7 \\
\hline Ciprofloxacin & 1 & 2.9 \\
\hline Metronidazole/Flagyl & 1 & 2.9 \\
\hline Amoxicillin & 2 & 5.7 \\
\hline Amoxicillin/Clavulanic acid & 3 & 8.6 \\
\hline Combination of antibiotics & 5 & 14.3 \\
\hline Herbal products & 0 & 0.0 \\
\hline Steroid (Dexamethasone) & 0 & 0.0 \\
\hline Alcoholic beverages & 1 & 2.9 \\
\hline Table 2B: Side effects of medications used & Frequency $(n=35)$ & Percentage $(\%)$ \\
\hline Body rashes & 0 & 0.0 \\
\hline Generalized pruritus or itching & 0 & 0.0 \\
\hline Worsening of condition or symptoms & 0 & 0.0 \\
\hline Yellow discolouration of eyes & 0 & 0.0 \\
\hline Facial or body swelling & 0 & 0.0 \\
\hline Vomiting & 1 & 2.9 \\
\hline Frequent passage of watery stools & 6 & 17.1 \\
\hline
\end{tabular}


Josephine Enekole Aitafo et.al. Self-Medication among health workers during the COVID-19 pandemic in Southern Nigeria: knowledge, patterns, practice and associated factors.

\begin{tabular}{|l|l|l|}
\hline \multicolumn{1}{|c|}{ Table 2C: Who prescribed the medication? } & Frequency $(\mathbf{n}=35) * *$ & Percentage $(\%)$ \\
\hline Medical personnel from health facility without COVID-19 screening & 10 & 28.6 \\
\hline Worker at chemist/pharmacy without COVID-19 screening & 1 & 2.9 \\
\hline A friend & 3 & 8.6 \\
\hline Prescription seen on social media & 5 & 14.3 \\
\hline Myself & 31 & 88.6 \\
\hline Table 2D: Where did you purchase the medicine used for self-medication? & Frequency (n=35)** & Percentage (\%) \\
\hline Patent medicine vendor & 3 & 8.6 \\
\hline Hospital & 12 & 34.3 \\
\hline Pharmacy & 29 & 82.9 \\
\hline Hawkers & 0 & 0.0 \\
\hline Faith-based outlet (Mosque/Church) & 1 & 2.9 \\
\hline Herbalist's outlet & 0 & 0.0 \\
\hline
\end{tabular}

\section{REASONS FOR SELF- MEDICATION.}

Four-fifths $(80 \%)$ of health workers that self-medicated reported that fear of being infected following contact with a suspected or confirmed case of COVID-19 was the main reason for self-medicating.
Emergency illnesses (45.7\%), fear of being stigmatized or discriminated against $(34.3 \%)$ and fear of being tested for COVID-19 were the other reasons enumerated by health workers who selfmedicated as demonstrated in Table 3.

\begin{tabular}{|l|l|l|}
\hline \multicolumn{2}{|c|}{ Table 3: what were your reasons for taking medications without prescriptions? } \\
\hline & Frequency $(\mathbf{n}=\mathbf{3 5}) * *$ & Percentage (\%) \\
\hline Fear of being tested for COVID-19 & 11 & 31.4 \\
\hline Fear of being stigmatized or discriminated & 12 & 34.3 \\
\hline Fear of self-isolation/quarantine & 10 & 28.6 \\
\hline Fear of being infected following contact with a suspected or confirmed COVID-19 case & 28 & 80.0 \\
\hline Delay in receiving treatment at designated health facilities & 9 & 25.7 \\
\hline Influence of friends to use self-medication as a first measure to prevent or treat COVID-19 & 11 & 31.4 \\
\hline Social media/TV/radio program influenced your decision to self-medicate & 3 & 8.6 \\
\hline Distance from health facility & 4 & 11.4 \\
\hline Emergency illness & 16 & 45.7 \\
\hline Closeness to a chemist/pharmacy & 6 & 17.1 \\
\hline No medicine in health facility & 1 & 2.9 \\
\hline Cost at the health facility & 5 & 14.3 \\
\hline
\end{tabular}

\section{FINDINGS FROM HEALTH WORKERS WHO DID NOT SELF- MEDICATE.}

For those who do not self-medicate,

$143(77.3 \%)$ responded that if they developed symptoms of COVID-19, their most likely option would be to call NCDC and get tested for COVID-19, although 25 $(13.5 \%)$ responded that self-isolation and self-treatment would be their preferred option, as seen in table 4 .

\begin{tabular}{|l|l|l|}
\hline \multicolumn{2}{|c|}{ Table 4: If you have symptoms suggestive of COVID-19 what would you most likely do? } \\
\hline & Frequency $(\mathbf{n = 1 8 5})$ & Percentage (\%) \\
\hline Call NCDC and get tested for COVID-19 & 143 & 77.3 \\
\hline Self-isolate and treat myself at home & 25 & 13.5 \\
\hline Self-isolate and watchfully wait for worsening clinical signs & 10 & 5.4 \\
\hline Self-isolate and watchfully wait for worsening clinical signs & 3 & 1.6 \\
\hline Self-quarantine and get a colleague to help administer treatment & 4 & 2.2 \\
\hline
\end{tabular}

\begin{tabular}{|l|l|l|}
\hline \multicolumn{2}{|c|}{ Table 5: What kind of medications/ therapy would you prefer? } \\
\hline \multicolumn{2}{|c|}{ Frequency (n=185)** } & Percentage (\%) \\
\hline Orthodox medications/therapy & 154 & 83.2 \\
\hline Herbal medications/therapy & 18 & 9.7 \\
\hline Spiritual healing prayers only & 6 & 3.2 \\
\hline Combination of both orthodox medicines and herbal therapy & 25 & 13.5 \\
\hline Combination of both orthodox medicines and spiritual healing prayers & 95 & 51.4 \\
\hline Combination of orthodox, herbal and spiritual healing prayers & 20 & 10.8 \\
\hline
\end{tabular}

** Multiple responses apply

Majority 154 (83.2\%) of respondents who did not self-medicate, also stated that peradventure symptoms of COVID-19 develop they would rather prefer orthodox 
Josephine Enekole Aitafo et.al. Self-Medication among health workers during the COVID-19 pandemic in Southern Nigeria: knowledge, patterns, practice and associated factors.

medications/ therapy and about half (51.4\%) responded that a combination of both orthodox and spiritual healing prayers will be their most preferred therapeutic options as demonstrated in Table 5.

\section{Relationship between HCWs' knowledge of self-medication and sociodemographic characteristics}

\begin{tabular}{|c|c|c|c|c|}
\hline \multicolumn{5}{|c|}{ Table 6: Bivariate analysis of knowledge of self-medication and sociodemographic characteristics } \\
\hline & \multicolumn{2}{|c|}{ Knowledge of self-medication } & \multirow[b]{2}{*}{ Chi-square } & \multirow[b]{2}{*}{ p-value } \\
\hline & Good $(\%)$ & Not Good (\%) & & \\
\hline \multicolumn{3}{|l|}{ Sex } & \multirow{3}{*}{1.46} & \multirow{3}{*}{0.26} \\
\hline Males & $53(62.4)$ & $32(37.6)$ & & \\
\hline Females & $73(54.1)$ & $62(45.9)$ & & \\
\hline \multicolumn{3}{|l|}{ Educational status } & \multirow{3}{*}{14.09} & \multirow[t]{3}{*}{$<0.001 *$} \\
\hline Tertiary & $120(61.9)$ & $74(38.1)$ & & \\
\hline Non-Tertiary & $6(23.1)$ & $20(76.9)$ & & \\
\hline \multicolumn{3}{|l|}{ Average Income } & \multirow{4}{*}{13.32} & \multirow{4}{*}{$0.001 *$} \\
\hline More than N500,000 & $15(53.6)$ & $13(46.4)$ & & \\
\hline $\mathrm{N} 100,000$ to $\mathrm{N} 500,000$ & $77(68.8)$ & $35(31.3)$ & & \\
\hline Less than N100,000 & $34(42.5)$ & $46(57.5)$ & & \\
\hline \multicolumn{3}{|l|}{ Status designation } & \multirow{9}{*}{ Fisher's Exact= 21.74} & \multirow{9}{*}{$0.001 *$} \\
\hline Auxiliary Nurse/Nurse Assistant & $10(34.5)$ & $19(65.5)$ & & \\
\hline CHEW & $1(50.0)$ & $1(50.0)$ & & \\
\hline Doctor & $74(67.3)$ & $36(32.7)$ & & \\
\hline Laboratory scientist/technician & $0(0.0)$ & $3(100.0)$ & & \\
\hline Non-medical health care staff & $9(42.9)$ & $12(57.1)$ & & \\
\hline Nurse/Midwife & $17(51.5)$ & $16(48.5)$ & & \\
\hline Pharmacist & $14(77.8)$ & $4(22.2)$ & & \\
\hline Warden & $1(25.0)$ & $3(75.0)$ & & \\
\hline \multicolumn{3}{|l|}{ Place of Practice } & \multirow{7}{*}{ Fisher's Exact $=5.92$} & \multirow{7}{*}{0.31} \\
\hline General Hospital & $5(71.4)$ & $2(28.6)$ & & \\
\hline Military Hospital & $2(33.3)$ & $4(66.7)$ & & \\
\hline Primary Health Centre & $12(80.0)$ & $3(20.0)$ & & \\
\hline Private establishment (Hospital/Clinic/Maternity) & $65(54.6)$ & $54(45.4)$ & & \\
\hline RSUTH & $24(61.5)$ & $15(38.5)$ & & \\
\hline UPTH & $18(52.9)$ & $16(47.1)$ & & \\
\hline \multicolumn{3}{|l|}{ Occupation } & \multirow{5}{*}{ Fisher's Exact= 1.69} & \multirow{5}{*}{0.67} \\
\hline Government Employed & $57(59.4)$ & $39(40.6)$ & & \\
\hline Private Employed & $63(57.3)$ & $47(42.7)$ & & \\
\hline Self Employed & $3(50.0)$ & $3(50.0)$ & & \\
\hline Unemployed & $3(37.5)$ & $5(62.5)$ & & \\
\hline
\end{tabular}

Table 6 shows that there is significant relationship between having a good knowledge of self-medication and respondents' educational level, income level and status designation.

\section{Relationship between HCWs' ever self-medication and sociodemographic characteristics}

Table 7 demonstrates there is a significant relationship between self-medication and the average income, level of education and occupation of study participants. Furthermore, the table also shows that all the respondents who had ever self-medicated were either doctors or nurses/midwives.

\begin{tabular}{|c|c|c|c|c|}
\hline & \multicolumn{2}{|c|}{ Ever self-medicate } & \multirow[b]{2}{*}{ Chi-square } & \multirow[b]{2}{*}{ p-value } \\
\hline & Yes $(\%)$ & No $(\%)$ & & \\
\hline \multicolumn{3}{|l|}{ Sex } & \multirow{3}{*}{0.313} & \multirow{3}{*}{0.71} \\
\hline Males & $15(17.6)$ & $70(82.4)$ & & \\
\hline Females & $20(14.8)$ & $115(85.2)$ & & \\
\hline \multicolumn{3}{|l|}{ Educational status } & \multirow{3}{*}{ Fisher's Exact $=$} & \multirow{3}{*}{$0.02 *$} \\
\hline Tertiary & $35(18.0)$ & $159(82.0)$ & & \\
\hline Non-Tertiary & $0(0.0)$ & $26(100.0)$ & & \\
\hline \multicolumn{3}{|l|}{ Average Income } & \multirow{4}{*}{16.00} & \multirow{4}{*}{$<0.001 *$} \\
\hline More than N500,000 & $10(35.7)$ & $18(64.3)$ & & \\
\hline $\mathrm{N} 100,000$ to $\mathrm{N} 500,000$ & $21(18.8)$ & $91(81.3)$ & & \\
\hline Less than N100,000 & $4(5.0)$ & $76(95.0)$ & & \\
\hline
\end{tabular}


Josephine Enekole Aitafo et.al. Self-Medication among health workers during the COVID-19 pandemic in Southern Nigeria: knowledge, patterns, practice and associated factors.

\begin{tabular}{|c|c|c|c|c|}
\hline \multicolumn{5}{|c|}{ Table 7 Continued... } \\
\hline Status designation & & & \multirow{9}{*}{ Fisher's Exact $=24.76$} & \multirow{9}{*}{$<0.001 *$} \\
\hline Auxiliary Nurse/Nurse Assistant & $0(0.0)$ & $29(100.0)$ & & \\
\hline CHEW & $0(0.0)$ & $2(100.0)$ & & \\
\hline Doctor & $30(27.3)$ & $80(72.7)$ & & \\
\hline Laboratory scientist/technician & $0(0.0)$ & $3(100.0)$ & & \\
\hline Non-medical health care staff & $0(0.0)$ & $21(100.0)$ & & \\
\hline Nurse/Midwife & $5(15.2)$ & $28(84.8)$ & & \\
\hline Pharmacist & $0(0.0)$ & $18(100.0)$ & & \\
\hline Warden & $0(0.0)$ & $4(100.0)$ & & \\
\hline Place of Practice & & & & \\
\hline General Hospital & $2(28.6)$ & $5(71.4)$ & & \\
\hline Military Hospital & $1(16.7)$ & $5(83.3)$ & & \\
\hline Primary Health Centre & $2(13.3)$ & $13(86.7)$ & Fisher's Exact $=13.91$ & $0.01 *$ \\
\hline Private establishment (Hospital/Clinic/Maternity) & $10(8.4)$ & $109(91.6)$ & & \\
\hline RSUTH & $10(25.6)$ & $29(74.4)$ & & \\
\hline UPTH & $10(29.4)$ & $24(70.6)$ & & \\
\hline Occupation & & & & \\
\hline Government Employed & $26(27.1)$ & $70(72.9)$ & & \\
\hline Private Employed & $9(8.2)$ & $101(91.8)$ & Fisher's Exact $=14.65$ & $0.001 *$ \\
\hline Self Employed & $0(0.0)$ & $6(100.0)$ & & \\
\hline Unemployed & $0(0.0)$ & $8(100.0)$ & & \\
\hline
\end{tabular}

\section{DISCUSSION}

All the respondents in our study were aware of COVID-19. This is not surprising as the respondents in our study were all health workers and thus most likely had prior information about Covid-19 in the course of their daily work; and also $88.2 \%$ of them had tertiary education. This is similar to the findings of Wegbom et $\mathrm{al}^{25}$ who reported $96.7 \%$ of respondents had sufficient knowledge about Covid-19. Though their study had a larger sample size of 461 respondents, it was also a questionnaire-web-based study in which $87.8 \%$ of respondents had tertiary education and thus likely had a broad knowledge base. Our study showed less than $2 / 3$ of respondents had good knowledge of what was meant by self-medication. This was less than that reported by Wegbom et $\mathrm{al}^{25}$ which showed $96.7 \%$ of respondents had sufficient knowledge of SM. The reason for this observation could not be readily explained as both studies had respondents with similar levels of education-both studies had about $89 \%$ of participants with tertiary education.

Our study showed only $15.9 \%$ of respondents admitted to having indulged in SM for Covid-19. Sadio et al ${ }^{17}$ in Togo reported a prevalence of SM for Covid-19 ranging from $16.4 \%$ to $51.9 \%$, with an overall prevalence of $34.2 \%$. Their study was a cross sectional study with 955 participants from 5 professional sectors: the road transport workers having the lowest prevalence and the health workers (which constituted $38.7 \%$ ) having the highest prevalence. They attributed this high prevalence to the long delay in finding adequate treatment/management for Covid19 based on adequate randomized trials, the influence of social media, political and religious leaders and the stigmatization of infected individuals; all of which encouraged people to treat themselves at home. ${ }^{17,31}$ Nasir et al ${ }^{26}$ reported a very high prevalence of $88.33 \%$ of SM during the Covid-19 pandemic. Their study was a cross-sectional on-line questionnaire-based study involving 626 individuals in Dhaka, India, who were not health workers, were mostly within the ages of 45-54 years and were mostly non-civil servants. Also most of the individuals in this study also thought they had Covid-19 or knew (21.08\%) because they had screened. Thus they were influenced by a feeling of insecurity caused by the fear of severe illness/death, the availability of medical resources and information about the prevention, treatment and control of Covid-19, both correct and incorrect, in the media (print, television and all social media platforms). Similar to the Dhaka study, the study by Quispe -Canari et $\mathrm{al}^{27}$ also reported majority of respondents self-medicated during the pandemic. This study like the Dhaka study, was based on responses by individuals from the general 
public and not health workers. Also it was a multicenter study involving a much larger sample size (3792 respondents) than that of our study population. Unlike our study, the study by Esan et al $^{28}$ also reported a high prevalence of SM of $81.8 \%$. This observed difference is not surprising because the study population were 384 undergraduate students of a private university in Ekiti State who were mostly between the ages of 19-23 years. Studies have shown that young people self-medicate more probably due to their low perception of risk associated with the use of drugs, their easy access to the Internet and media coverage of health related issues and ready access to drugs. ${ }^{28,}$ 29,30

Our study showed the top 5 medications used by health workers were tabs Vitamin C, Zinc, Azithromycin, antimalarials (other than Hydroxychloroquine) and Hydroxychloroquine (HCQ). Similarly, Wegbom et $\mathrm{al}^{25,32}$ reported Vitamin $C$ and antimalarials other than HCQ as being amongst the top 5 drugs used for SM. However, they reported their respondents also used antibiotics like amoxicillin and ciprofloxacin and herbal products commonly. HCQ was used in only $1.3 \%$ unlike that reported in this present study where $34.3 \%$ of respondents used HCQ. This is not surprising as the respondents in our study were all health care workers unlike the study population in the study by Wegbom et al. ${ }^{25}$ Similar to our study Sadio et al ${ }^{17,32}$ also reported Vitamin $\mathrm{C}$, HCQ and Azithromycin amongst the drugs most commonly used. However, $10.2 \%$ of their respondents also used traditional medication. Their study population apart from health care workers also included air and road transport workers, the police and artisans. In contrast to that reported by our study, Nasir et $\mathrm{al}^{26}$ in Dhaka reported very common use of Ivermectin for SM (77.2\%), as well as Azithromycin, Montelukast, calcium supplements, doxycycline and HCQ. Quispe-Canari et $\mathrm{al}^{27}$ in Peru reported the use of Azithromycin, Acetaminophen, HCQ, Antiretrovirals,
Penicillin and Ibuprofen as drugs for SM during the lockdown period. Minan-Tapia also in Peru reported the use of Acetaminophen, Ibuprofen, Dexamethasone, Aspirin and Azithromycin for SM during the pandemic. ${ }^{32}$ The choice of drugs to use during this pandemic was largely influenced by availability in the different locations which was largely affected by importation challenges, travel restrictions and cost implications and the hype via different communication channels especially social media. Vitamin $\mathrm{C}$ as well as been cheap and readily available, has been reported to be effective in the management/prevention of Covid-19. ${ }^{17}, 25$, ${ }^{33} \mathrm{HCQ}$ though less available and costly, was also widely used for SM because it had been reported to reduce to reduce viral load and shorten recovery time in Covid-19 patients. ${ }^{34,} 35$ However improper use may result in arrhythmias or even death. ${ }^{34,35}$

Our respondents reported very few side effects with diarrhea being the most common. In contrast, Wegbom et $\mathrm{al}^{25}$ reported body rash as being most common adverse effect followed by worsened condition, yellowish eyes and severe diarrhea. This difference in side effects observed may possibly be due to the fact that the respondents in the study by Wegbom also used herbal concoctions which may be hepatotoxic when used in excess.

Our study showed majority (88.9\%) prescribed the drugs for themselves without any confirmatory test being done. This was followed by prescriptions from other health personnel and then from prescriptions seen on social media. This underscores the importance of the health sector engaging Health care workers and the general public with the right evidence-based information through all communication platforms especially social media in this present age. Similarly, Wegbom et al ${ }^{25}$ reported more than half of their respondents had prescribed the drugs by themselves, over one-third from prescriptions by other medical personnel and others from recommendations 
by friends. Majority of the respondents in our study purchased the drugs mainly from the pharmacy $(82.9 \%)$, others from the hospital and the patent medicine vendor. Similarly, Wegbom et $\mathrm{al}^{25}$ also in Nigeria, reported majority $(73.9 \%)$ of respondents purchased their drugs from the pharmacy and the patent medicine vendor $(23.6 \%)$.

Our study showed majority selfmedicated because of the fear of getting infected following contact with a suspected or confirmed case of Covid-19. Others reasons given include emergency illnesses, fear of being stigmatized and the fear of being tested for Covid-19. Wegbom et $\mathrm{al}^{25}$ also reported the fear of getting infected as the most common reason for SM. They also reported the delay in receiving treatment at health facilities, the influence of friends and social media, non-availability of medications for treatment at the Covid-19 treatment centers, distance to the health facility and cost as reasons for SM. MinanTapia also reported in a study among young undergraduate students in Peru, believing the symptoms were not severe enough to go to a doctor as reason and cost as reasons for SM. ${ }^{32}$ Arain et $\mathrm{al}^{36}$ in Pakistan, reported that in addition to the fear of getting infected the lockdown was a major reason for SM.

Our study showed that for those who did not self-medicate, majority $(77.3 \%)$ said if they developed symptoms suggestive of Covid-19 they would call NCDC and get tested. Others $(13.5 \%)$ said they would prefer to self-isolate and treat themselves at home. Majority also said they would prefer to use orthodox medications for treatment. About half however reported they would prefer a combination of orthodox drugs and spiritual healing prayers. This buttresses the fact that there is a need to engage spiritual and cultural leaders in creating awareness about Covid-19 and its' proper management as people are greatly influenced by their spiritual and cultural beliefs.

Our study showed having a good knowledge of SM was significantly associated with respondents' educational level, income level and status designation.
This finding was not surprising and has been reported by other studies. ${ }^{17,25,27}$ Our study also showed significant association between SM and the respondents' average income, status designation and occupation status. These findings could be due to the fact that educated people and those of higher socio-economic status have greater access to the internet and may have greater understanding of treatment information published on social media. Our study showed respondents who self-medicated were either doctors or nurses/mid-wives. This is similar to that reported by Sadio et al ${ }^{17}$ which showed SM was significantly associated with working in the health sector.

\section{CONCLUSION}

Though majority of health-workers knew about Covid-19, less than $2 / 3$ have good knowledge about SM. The prevalence of SM amongst health-workers in Rivers state was found to be $15.9 \%$. SM is commoner with those with higher income, those who are doctors or nurses and those who work with the government. The most common drugs used for SM included Vitamin C, Zinc, Azithromycin, antimalarials and HCQ. Reasons for SM included the fear of getting infected and the fear of being stigmatized. The need to engage the government bodies, health organizations, religious and cultural organizations to inform and educate health workers and the general public about Covid19, it's management and evidence based prevention methods, via all platforms of information dissemination including social media cannot be over-emphasized.

Acknowledgement: None

Conflict of Interest: None

Source of Funding: None

Ethical Approval: Approved 
Josephine Enekole Aitafo et.al. Self-Medication among health workers during the COVID-19 pandemic in Southern Nigeria: knowledge, patterns, practice and associated factors.

\section{REFERENCES}

1. World Health Organization (WHO). Coronavirus disease (2019) Covid-19 Situation Report-94. Available online at: http://www.who.int/docs/defaultsource/coronaviruse/situation reports/20200423-sitrep-94-covid19.pdf?sfvrsn=b8304bf0-4. Accessed 21/08/2021

2. Al-Mandhari A, Samhouri D, Abubakar A, Brennan R. Coronavirus Disease 2019: Preparedness and readiness of countries in the Eastern Medi-terranean Region. East Mediterr Health J 2020; 26(2): 136-137. https://doi.org/10.26719/2020.26.2.136

3. World Health Organization 2020 Situation Report. Geneva, Switzerland: WHO. Available at: https://www.who.int/emergencies/diseases /novel-coronavirus-2019/situationreportsAccessed 21/08/2021

4. NCDC Covid-19 Situation Report, Epi Week $5221^{\text {st }}-27^{\text {th }}$ December 2020, State of the Nation. Available at: https://ncdc.gov.ng/themes/common/files/ sitreps/517209c45e82a6b1856097c6a37a7 f68.pdfAccessed 21/08/2021

5. Nigeria Centre for Disease Control. Available at: https://ncdc.gov.ng/news/227/first-caseof-corona-virus-disease-confirmed-inNigeriaAccessed 21/08/2021

6. World Health Organization. WHO Announces Covid-19 outbreak a Pandemic. Available at: http://www.euro.who.int/en/healthtopics/health-emergencies/coronavirus...Accessed 21/08/2021

7. Owings L. Africa 'not ready' for Covid19. Mental Health Issues 2020. Available at: $\quad$ https://is.gd/EVhGdQAccessed $21 / 08 / 2021$

8. World Health Organization (WHO). WHO supports scientifically-proven traditional medicine (2020). Available at: https://www.afro.who.int/news/whosupportsscientifically-proventradition...Accessed 20/08/2021

9. Hernandez-Juyol M, Job-Quesada JR. Dentistry and self-medication: A current challenge. Med Oral 2002; 7: 344-347
10. Afridi MI, Rasool G, Tabassum R et al. Prevalence and pattern of self-medication in Karachi: a community survey. Pak J Med Sci 2015; 31(5): 124-125. doi:10.12669/pjms.315.8216

11. Noone J, Blanchette CM. The value of self-medication: summary of existing evidence. J Med Econ 2018; 21(2): 201204 doi:10.1080/13696998.2017.1390473

12. World Health Organization. Coronavirus disease (Covid-19) advice for the public: mythbusters

https://www.who.int/emergencies/diseases /novel-coronavirus-2019/advice-forpublic/myth-bustersAccessed 20/8/2021

13. Oyediran O, Ayandirian EO, Olatubi MI. Awareness of risk associated with selfmedication among patients attending outpatient department of a tertiary hospital in South Western Nigeria. Int J Afr Nurs Sci 2019; 10: 110-115

14. Ayanwale MB, Okafor IP, Odukoya OO. Self-medication among rural residents in Lagos, Nigeria. J Med Trop 2017;19: 6571.10.4103/jomt.jomt_51_16-DOI

15. Babatunde OA, Fadare JO, Ojo OJ, Durowade KA, Atoyebi OA, Ajayi PO et al. Self-medication among health workers in a tertiary institution in South-West Nigeria. Pan Afr Med J 2016; 24: 312. 10.11604/pamj.2016.24.312.8146-DOI

16. Oshikoya KA,Senbanjo IO, Njokanma OF. Self-medication for infants with colic in Lagos, Nigeria. BMC Paediatr 2009;9: 9. 10.1186/1471-2431-9-9-DOI

17. Sadio AJ, Gbeasor-Komlanvi F, Konu RY, Bakoubayi AIV, Tchankon MK, Bitty-Anderson A, Gomez IM, Denadou CP, Anani J, Kouanfack HR, Kpeto IK, Salou M, Ekouevi DK. Assessment of self-medication practices in the context of Covid-19 outbreak in Togo. Research Square DOI: https://doi.org/10.21203/rs42598/v1

18. Dare SS, Eze ED, Isaac E, Usman IM, Ssempijja F, Bukenya EE, Ssebuuju R. Covid-19 Pandemic and behavioural response to self-medication practice in Western Uganda. MedRxiv 2021: doi:https://doi.org/10.1101/2021.01.2.202 48576 
19. Eticha T, Mesfin K. Self-medication practices in Mekelle, Ethiopia. PLoS ONE 2014; 9(5): e97464 doi:10.1371/journal.pone.0097464

20. Azami-Aghdash S, Mohseni M, Elemadi $M$ et al. Prevalence and cause of selfmedication in Iran: a systematic review and meta-analysis article. Iran $\mathrm{J}$ Public Health 2015; 44(12): 1580-1593

21. World Health Organization. Report of the WHO Expert Committee on National Drug Policies. Geneva, Ed 1995. Available at: https://apps.who.int/iris/handle/10665/630 68?locale-

attribute $=$ en $\&$ show $=$ fullAccessed 20/08/2021

22. Hughes CM, McElnay JC, Fleming GF. Benefits and risks of self-medication. Drg Saf 2001; 24: 1027-1037

23. Cherian D. Covid-19: Avoid selfmedication and false 'cures' when battling coronavirus. 2020. Available at: https://gulfnews.com/world/americas/covi d-19-avoid-self-medication-and-falsecures-when-battling-coronavirus1.1585042404259

24. Busari S, Adebayo B. Nigeria records chloroquine poisoning after Trump endorses it for coronavirus treatment. 2020. Available at: https://edition.cnn.com/2020/03/23/africa/ chloroquine-trump-nigeria-intl/index.html

25. Wegbom AI, Edet CK, Raimi O, Fagbamigbe AF, Kiri VA. Selfmedication practices and associated factors in the prevention and/or treatment of Covid-19 virus: A population-based survey in Nigeria. Front Public Health 2021; 9: 606801 doi:10.3389/fpubh.2021.606801

26. Nasir M, Chowdhury ASMS, Zahan T. Self-medication during Covid-19 outbreak: a cross sectional online survey in Dhakar city. Int J Basic Clin Pharmacol 2020; 9(9): 1325-1330. DOI: https://dx.doi.org/10.18203/23192003.ijbcp20203522

27. Quispe-Canari JF, Fidel-Rosales E, Manrique D, Mascaro-Zan J, HuamanCastillion KM, Chamorro-Espinoza SE, Garayar-Peceros $\mathrm{H}$ et al. Self-medication practices during the Covid-19 pandemic among the adult population in Peru: A cross-sectional survey. Saudi Pharm J 2021; 29(1): $1-11$ doi:10.1016/j.jsps.2020.12.001

28. Esan DT, Fasoro AA, Odesanya OE, Esan TO, Ojo EF, Faeji CO. Assessment of Self-Medication Practices and it's associated factors among undergraduates of a private university in Nigeria. Journal of Environmental and Public Health. 2018; Article ID 5439079, 7 pages. Doi: 10.1155/2018/5439079

29. Flaiti MA, Badi KA, Hakami WO, Khan SA. Evaluation of self-medication practices in acute diseases among university students in Oman. Journal of Acute Disease. 2014; 3(3): 249-52.

30. Simone ED, Tartaglini T, Fiorinin S, Petriglieri S, Plocco C, Muzio MD. Medication errors in intensive care units: nurses training needs. Emergency Nurse. 2016; 24(4): 24-9.

31. World Health Organization (WHO), United Nations of International Children's Emergency Fund(UNICEF), international federation of Red cross and Red Crescent Societies (IFRC). Social Stigma Associated with Covid-19. Geneva: WHO, UNICEF, IFRC;2020, p 5p.

32. Quincho-lopez A, Benites-Ibarra CA, Hilario-Gomez MM, Quinjano-Escate R, Taype-Rondan A. Self-medication practices to prevent or manage COVID19: A systematic review. PLoS ONE. 2021; 16(11): e0259317. https://doi.org/10.1371/journal.pone.0259 317

33. Chu W. Hospital turns to high dose Vitamin C to fight coronavirus. (2020). Available online at: https://www.nutraingredients.com/Article/ 2020/03/25/hospital-turns-to-high-

dosevitamin-C to -fightcoronavirus?utm_sourcecopyright\&utm medium=Onsite\&utm_campaign=copyrig ht. 27

34. Megarbane B. Chloroquine and hydroxychloroquine to treat COVID-19: between hope and caution. Clin Toxicol (Phil).
2020:1-2. 
Josephine Enekole Aitafo et.al. Self-Medication among health workers during the COVID-19 pandemic in Southern Nigeria: knowledge, patterns, practice and associated factors.

https://doi.org/10.1080/15563650.2020.17 48194.

35. Gautret P, lagier JC, Parola P, Hoang VT, Meddeb L, Mailhe M, et al. Hydroxychloroquine and azithromycin as a treatment of COVID-19: results of an open-label non-randomized clinical trial. Int J antimicro Agents. 2020; 20:105949. Doi: 10.1016/j.ijantimicag.2020.105949

36. Arain MI, Shahnaz S, Anwar R, Anwar K. Assessment of Self-medication Practices during Covid-19 Pandemic in Hyderabad and Karachi, Pakistan. Sudan Journal of Medical Sciences. 2021; 16(3): 347-54. DOI: $10.18502 /$ sjms.v1613.9696

How to cite this article: Josephine Enekole Aitafo, Woroma Wonodi, Datonye Christopher Briggs et.al. Self-medication among health workers during the COVID-19 pandemic in Southern Nigeria: knowledge, patterns, practice and associated factors. Int $J$ Health Sci Res. 2022; 12(2): 163-175. DOI: https://doi.org/10.52403/ijhsr.20220223 